\section{Debate is failing Europe's geneticists}

Countries such as the United States, where gene-edited plants are already grown and commercialized, will profit while the European Union continues to debate regulations governing their use. Your recommendation to spend the waiting time in public dialogue is a slap in the face for European scientists working with these technologies (Nature 542, 392; 2017).

Although public debate and biosafety evaluations are hugely important, European debates on genetic modification all too often end in deadlock - that of the Leopoldina (Germany's national science academy) being the most recent example. Further delays are likely if the European Court of Justice (ECJ) decides next year that gene-edited plants and animals should be considered as genetically modified organisms and therefore be subject to increased regulation. Meanwhile, gene-edited cultivars are waiting for outdoor field testing.

The European Commission set up a working group in 2007 to assess new breeding techniques within its legislation framework for genetically modified organisms. In 2011, it declared that only the ECJ can give a binding opinion on $\mathrm{EU}$ legislation for the products of these techniques. Today, the issue still lies dormant at the ECJ, with no end in sight after ten years (see also M. Fladung Nature Biotechnol. 34, 473-474; 2016). Matthias Fladung Thünen Institute of Forest Genetics, Grosshansdorf, Germany. matthias.fladung@thuenen.de

\section{Close Hong Kong's ivory-trade window}

China and Hong Kong will stop their domestic trading in ivory by the end of 2017 and by 2021, respectively. Hong Kong must speed up its ivory ban to avoid this mismatch, which leaves open a four-year window for smuggling ivory legally purchased in Hong Kong into mainland China. This will fuel sales in one of the world's largest ivory retail markets.

As a major ivory transit conduit where illegal ivory is laundered through legal retailers (see go.nature.com/2oby6jb), Hong Kong is designated by the Convention on International Trade in Endangered Species as a 'country of primary concern' (see go.nature.com/2ncroed). The annual 45 million visitors from mainland China account for $90 \%$ of ivory purchases in Hong Kong (go.nature.com/2njhb5z).

Now that Hong Kong has decided to ban the trade, we urge its government to coordinate with Beijing and align its plans with those of China.

Hubert Cheung University of Queensland, Brisbane, Australia. Rebecca W. Y. Wong City University of Hong Kong. Duan Biggs Griffith University, Nathan, Queensland, Australia. h.cheung@uqconnect.edu.au

\section{UK universities and European industry}

UK universities and the

European business sector have long been inseparable research partners. As Britain prepares to leave the European Union, many decades' worth of UK investment in valuable human capital and vulnerable social capital is at risk.

We investigated patterns of research collaboration between 47 UK universities and industry (see go.nature.com/2ms8cx5). The information was extracted from some 30,000 publications during 2009-15 that had authors from both UK universities and industry. EU-based industry is mentioned in $24 \%$ of these co-authored publications (UK-based firms account for $39 \%$ ), with many universityindustry 'crossover' researchers also affiliated to at least one of these 47 universities.

Just 8 UK universities account for $48 \%$ of collaborative papers with EU-based firms: Imperial College London, King's College London, University College London and the universities of Cambridge, Edinburgh, Glasgow, Manchester and Oxford. Each of these produced 400 or more such co-publications and had 30 or more researchers associated with an EU-based firm, sometimes simultaneously.

Upcoming Brexit negotiations must include protection of these valuable UK-based university researchers who populate productive intersections with European industry.

Robert Tijssen, Alfredo Yegros Leiden University,

the Netherlands.

tijssen@cwts.leidenuniv.nl

\section{Reduce inequality to reduce abortion}

I take issue with Malcolm Potts and colleagues' contention that the "best way to prevent abortions is to invest heavily in accessible family planning" (Nature 542, 414; 2017). Counteracting socio-economic and gender inequalities is just as important.

From 1990 to 2014, the abortion rate declined in the developed world and remained relatively constant in the developing world, despite an increase in funding for contraception and familyplanning services (G. Sedgh et al. Lancet 388, 258-267; 2016). Educating women and shifting social norms are as essential as improving access to contraception: only about $10 \%$ of women in the developing world who want to avoid pregnancy report being unaware of contraceptive methods, having inadequate access to them or finding the cost prohibitive (see go.nature.com/2okskfe).

Abortion may be a symptom of poverty. According to a 2014 census, $33.4 \%$ of the US population are in the lowincome bracket (see go.nature. com/2ie6agn); this group accounts for $75 \%$ of abortions (see go.nature.com/2ns9qkj). One of the most common reasons given for seeking abortion is being unable to afford a child (M. Kirkman et al. Arch. Women's Ment. Health 12, 365-378; 2009). Furthermore, the high rate of sexselective abortion in some parts of the world is driven by pejorative perceptions of women that are born out of gender inequality. Chika E. Uzoigwe Sheffield, UK. chika@doctors.org.uk

\section{Local problems are a low research priority}

You ask what science can do for those who voted for US President Donald Trump, suggesting that it would be useful to work with local communities on research problems that could improve their quality of life (Nature 542, 391; 2017). I disagree.

Most people forget that curiosity-driven research by James Clerk Maxwell, Heinrich Hertz, Hans Christian Ørsted, André-Marie Ampère and Michael Faraday gave us electricity and radio. Without Christian Gottfried Ehrenberg, Louis Pasteur and Robert Koch, our hospitals would not work. Max Planck, Ernest Rutherford, Niels Bohr, Albert Einstein and others founded the knowledge for techniques on which today's world is reliant - not least, microprocessors, the Global Positioning System and mobile phones. Results from DNA technology are still just the tip of the iceberg. And, thanks to Tim Berners-Lee, the World Wide Web has transformed communication.

Universities are global institutions that have the primary objectives of creating knowledge and educating people to continue the development of our societies. Building stronger links with local society and solving local problems should never be a priority for any university. Ole John Nielsen University of Copenhagen, Denmark. ojn@kiku.dk 